\title{
4 CARA UNTUK MENCINTAI HINGGA JANGKA PANJANG
}

\author{
Akhmad Fauzi Afandi \\ Universitas Nahdlatul Ulama Sidoarjo \\ akhmad.islam.surga@gmail.com
}

Keempat strategi ini akan membantu Anda menyuburkan dan mempertahankan hubungan romantis yang erat.

\section{Hargai kejutan.}

Bagian dari keajaiban kekasih Anda adalah persis apa yang tidak diketahui: Menemukan bahwa pasangan Anda menyukai pembakaran kayu sebagai seorang anak, memainkan klarinet di sekolah menengah, atau belajar bahasa Perancis di kelas tiga dan masih menyukai bahasa. Menonton kegembiraannya ketika dia bermain dengan anak anjing atau miliknya ketika dia makan es krim karamel asin. Penemuan yang Anda lakukan tentang pasangan memungkinkan Anda untuk melihatnya sebagai unik.

\section{Terima sifat atau kebiasaan yang berpotensi menyebalkan.}

Mencoba mengubah seseorang menjadi apa yang Anda inginkan kepadanya sering membuat hubungan putus asa dengan kegagalan melalui mati lemas. Biarkan penilaian melunak, dan biarkan keterbatasan dan kerentanan untuk dipeluk: Jangan menolak bagian dari keseluruhan orang. Tidak apa-apa kalau dia ditantang secara mekanik atau dia seorang tolol. Mengenal dan menerima kehidupan nyata (bukan orang yang diidealkan) adalah proses seumur hidup tetapi penting untuk mempertahankan sihir.

\section{Pahamilah bahwa gairah memiliki siklus.}

Pada akhirnya, emosi adalah label yang kita berikan kepada bahan kimia yang mengalir melalui tubuh kita, dikombinasikan dengan cara tubuh kita, pikiran, dan impuls bereaksi terhadap mereka. Kita bisa, memang, mengubah emosi - kimia kita - dengan mengubah persepsi atau perspektif kita, perilaku kita, atau situasi di mana kita menempatkan diri kita. Ambil napas yang lambat dan dalam dan amati pergeseran internal Anda. Semakin cepat kita membiarkan pengaruh pemicu eksternal menghilang dan pusat internal kita yang tenang membimbing kita, semakin cepat kita akan dapat melihat di mana hati kita mengarahkan kita. Kemudian kita bisa mengikutinya dan bukannya melarikan diri darinya. Selama serangan kegembiraan habis-habisan, biarkan emosi Anda mengalir dengan bebas ketika mereka terangsang, menyensor tindakan bila perlu, dan tahu apa yang membantu Anda kembali ke garis dasar Anda. Saya penggemar berat meditasi, peregangan, dan refleksi, tetapi aktivitas apa pun yang dilakukan: Pertimbangkan doa, berlari, menjadi sukarelawan, terlibat dengan hewan peliharaan, atau tidur malam yang nyenyak.

\section{Perluas pengetahuan dan bagikan ketakutan rahasia Anda.}

Semakin Anda memahami bagaimana perasaan pasangan Anda, apa yang dia pikirkan, dan mengapa dia berperilaku seperti yang dia lakukan, semakin Anda sepenuhnya 
dapat saling berpelukan. Energi yang dibutuhkan untuk menyembunyikan rahasia dari kesadarannya sendiri atau kesadaran orang lain mengambil tol dengan membatasi energi yang tersedia untuk aliran emosi. Gairah tumbuh ketika hambatan ini dihapus. 